\title{
GARANTÍSTICA E FLEXIBILIZAÇÃO PROCEDIMENTAL ${ }^{1}$
}

\section{LEGAL PROCESS AS A GUARANTEE AND PROCEDURAL FLEXIBILITY}

Igor Raatz

Pós-doutor, doutor e mestre em Direito pela Universidade do Vale do Rio dos Sinos - UNISINOS. Especialista em processo civil pela Academia Brasileira de Direito Processual Civil ABDPC. Membro do DASEIN - Núcleo de Estudos Hermenêuticos. Membro da ABDPro - Associação Brasileira de Direito Processual. Membro do IIDP - Instituto Iberoamericano de Direito Processual. Professor no curso de graduação em Direito da Universidade FEEVALE. Professor em cursos de pós-graduação e extensão em direito processual civil. Advogado. Porto Alegre/RS. E-mail: igor@ raatzanchieta.com.br

Natascha Anchieta Doutoranda e Mestre em Direito pela Universidade do Vale do Rio dos Sinos - UNISINOS. Especialista em Direito pela Associação dos Juízes do Estado do Rio Grande do Sul AJURIS. Membro da ABDPro - Associação Brasileira de Direito Processual. Membro do IIDP - Instituto Iberoamericano de Direito Processual. Professora em cursos de pós-graduação e extensão em direito processual civil. Advogada. Porto Alegre/RS. E-mail: natascha@raatzanchieta.com.br

\footnotetext{
${ }^{1}$ Artigo recebido em 13/01/2021 e aprovado em 20/04/2021.
} 
William Galle Dietrich

Doutorando em Direito pela Universidade de São Paulo USP. Mestre em Direito pela Universidade do Vale do Rio dos Sinos - UNISINOS, como bolsista CAPES. Bacharel em Direito pela Universidade FEEVALE. Membro da ABDpro. Professor em cursos de pós-graduação e extensão em direito processual civil. Advogado. Porto Alegre/RS. galledietrich@gmail.com

RESUMO: $O$ artigo trabalha com a questão da flexibilização procedimental sob a perspectiva da garantística. Partindo de uma metódica dogmática, busca diferenciar flexibilização do procedimento e adaptabilidade da tutela jurisdicional. Demonstra que as críticas realizadas ao procedimento comum e à rigidez procedimental no Brasil seguem premissas da doutrina italiana. Elucida que a crítica garantística à flexibilização procedimental pelo juiz não significa um menosprezo ao direito material. Observa, por fim, questões de direito comparado. Faz-se uso do método de revisão bibliográfica, na construção de premissas, e do método dedutivo na formulação das teses defendidas pelo estudo.

PALAVRAS-CHAVE: Garantística. Flexibilização procedimental. Adaptabilidade da tutela jurisdicional. Ordinariedade. Dogmática jurídica.

ABSTRACT: The article deals with the issue of procedural flexibility from the perspective of the theory of the legal process as a guarantee. Starting from a dogmatic method, it seeks to differentiate the flexibility of the procedure and the adaptability of jurisdictional protection. It demonstrates that the criticisms made to the common procedure and procedural rigidity in Brazil follow premises of Italian doctrine. It clarifies that the criticism of procedural flexibility by the judge does not mean a disregard for material right. Finally, it looks at issues of comparative law. The bibliographic review method is used, in the construction of premises, and the deductive method in the formulation of the theses defended by the study. 
KEYWORDS: Legal process as a guarantee. Procedural flexibility. Adaptability of jurisdictional command. Ordinariness. Legal dogmatics.

\section{Introdução}

Com o advento da legislação procedimental civil de 2015, um dos temas que mais empolgaram a doutrina brasileira foi o da flexibilização procedimental. O modo como a questão vem sendo apresentada parte, por um lado, de uma crítica ao procedimento comum na sua feição anterior - que, como veremos, estaria marcada por aquilo que Ovídio A. Baptista da Silva denominava de "mito da ordinariedade" - e, por outro, da afirmação no sentido de que o art. $327, \S 2 .^{\circ}$ do CPC permite inferir uma cláusula geral de flexibilização do procedimento comum ${ }^{2}$. Essa abordagem, por sua vez, costuma relacionar-se com o estudo dos procedimentos especiais, questionando tanto a sua pertinência, quanto as possibilidades de uma teoria geral dos procedimentos especiais.

Desse modo, este artigo se propõe a esclarecer algumas questões importantes. Em primeiro lugar, mostra que a doutrina brasileira vem realizado uma verdadeira confusão conceitual entre flexibilização do procedimento e adaptabilidade da tutela jurisdicional. Em segundo lugar, demonstra que as críticas realizadas ao procedimento comum e à rigidez procedimental no Brasil seguem o mesmo equívoco cometido pela doutrina italiana a respeito das chamadas "tutelas jurisdicionais diferenciadas", com a diferença que - ao contrário do direito italiano, no qual esse equívoco culminou na proliferação desmedida de procedimentos especiais -, no Brasil, ele tem conduzido à defesa constante da flexibilização do procedimento em detrimento da legalidade. Em terceiro lugar, explica que a crítica da garantística à flexibilização procedimental pelo juiz não significa um menosprezo ao direito material e à efetividade da tutela jurisdicional prestada pelo Estado ao indivíduo. Em quarto lugar, por fim, esclarece que naqueles ordenamentos jurídicos em que a adaptação

\footnotetext{
${ }^{2}$ Nesse sentido, com maior repercussão na doutrina brasileira, DIDIER JR., Fredie; CABRAL, Antônio do Passo; CUNHA, Leonardo Carneiro da. Por uma nova teoria dos procedimentos especiais: dos procedimentos às técnicas. Salvador: Juspodivm, 2018. Na mesma linha, com ampla referência favorável à referida tese, CERQUEIRA, Társis Silva de. O procedimento comum e sua relação com os procedimentos especiais: a análise do conteúdo normativo do art. $327, \$ 2 .^{\circ}$, do Código de Processo Civil. Salvador: Juspodivm, 2020.
} 
procedimental é prevista na lei, ela não se dá mediante a construção de um procedimento pelo juiz tal qual se costuma defender no Brasil.

\section{Da defesa dos marcos essenciais do procedimento legal ao reconhecimento das especificidades decorrentes da tutela jurídica certificada pela tutela jurisdicional: contribuições de Calmon de Passos}

Para o garantismo processual/garantística ${ }^{3}$ a diferença entre processo e procedimento reside no âmbito normativo: o processo é um direito fundamental de resistência ${ }^{4}$ (art. 5, LIV, CF) e, portanto, está contemplado no plano constitucional; o procedimento é construído pelo legislador infraconstitucional, refletindo e corporificando, mediante uma regulamentação de atos concretos previamente regulamentados, as possibilidades de exercício pelas partes do direito fundamental ao devido processo e dos demais direitos fundamentais que lhe são componentes (v.g., direito ao contraditório, direito à fundamentação das decisões judiciais, direito à igualdade, direito à legalidade, etc.). Não há processo sem procedimento capaz de corporificá-lo; contudo, o que dá vida ao procedimento jurisdicional é o conteúdo normativo-constitucional estabelecido pelo devido processo. Em linhas gerais, a norma constitucional do art. 5. ${ }^{\circ}, \mathrm{LIV}, \mathrm{CF}$, desmembra-se em três elementos: o processo (conteúdo normativo-constitucional composto por uma série de direitos fundamentais de resistência oponíveis ao detentor do poder jurisdicional), que é devido (vale dizer, necessário para que ocorra a atuação jurisdicional e o contato do Estado-juiz com a esfera jurídica dos indivíduos) e legal, no sentido de que é instituído pela lei por meio de um procedimento 5 .

\footnotetext{
${ }^{3}$ Para uma explicação dos termos, ver COSTA, Eduardo José da Fonseca. Garantismo ou garantística. Empório do direito. Coluna Garantismo Processual, n. 78. Disponível em: <https://emporiododireito.com.br/leitura/78-garantismo-ou-garantistica〉. Acesso em 05.01.2020.

${ }^{4}$ Sobre o tema, ver RAATZ, Igor. Processo, liberdade e direitos fundamentais. Revista de processo. Ano 44. Vol. 288. Fevereiro de 2019. São Paulo: Revista dos Tribunais, 2019. DALLA BARBA, Rafael Giorgio. Se o processo é uma garantia de liberdade, ele é um direito de defesa. Empório do direito. Coluna Garantismo Processual, n. 46. Disponível em: <https://emporiododireito.com.br/leitura/46-se-o-processo-e-umagarantia-de-liberdade-ele-e-um-direito-de-defesa>. Acesso em 05.05.2020.

${ }^{5}$ Nesse sentido, ver COSTA, Eduardo José da Fonseca. O processo como instituição de garantia. Consultor jurídico. 16 de nov. de 2016. Disponível em <https://www.conjur.com.br/2016-nov-16/eduardo-jose-costaprocesso-instituicao-garantia >. Acesso em 10.05.2020. Também COSTA, Eduardo José da Fonseca. Notas para uma garantística. Empório do direito. Disponível em <http://emporiododireito.com.br/leitura/abdpro40-notas-para-uma-garantistica>. Acesso em 05.07.2018.
} 
Enquanto fenômeno da realidade, aquilo que comumente é denominado de processo jurisdicional possui uma dimensão muito mais abrangente que o conteúdo normativo conferido ao processo e ao procedimento. Sob essa perspectiva, Calmon de Passos, após considerá-lo "um comportamento mediante o qual sujeitos desavindos pretendem obter, de um terceiro, uma solução revestida de impositividade, isto é, em condição de submeter a sua eficácia quem vier a ser vencido", busca assentar tal fenômeno em quatro pilares, quais sejam, postulação, instrução, decisão e efetivação. É claro que, nesse âmbito, trata-se de explicar aquilo que ocorre na realidade quando observamos um processo jurisdicional, e não de explicitar o conteúdo normativo do processo encarado como um direito fundamental do indivíduo. Portanto, segue-se que os interessados exteriorizam suas pretensões (ato de postulação) a um terceiro (alguém, portanto, estranho aos acontecimentos narrados pelas partes) que, após a instrução da causa, venha a decidir e, a partir daí, efetivar aquilo que foi decidido ${ }^{6}$.

Contudo, o modo como essas atividades de postulação, instrução, decisão e efetivação deverão ocorrer não é livre. Segundo Calmon, “deverá haver uma definição prévia de como realizar essas atividades", respeitando-se, nesse percurso, o contraditório, a igualdade, a fundamentação das decisões judiciais, as quais, por sua vez, deverão estar submetidas a controles de sua conformidade com o previamente posto como direito, evitando possíveis arbítrios por parte do órgão jurisdicional. Esse itinerário, que contempla as atividades de postulação, instrução, decisão e efetivação dos provimentos jurisdicionais, constitui o elemento essencial de qualquer processo jurisdicional, independentemente do procedimento que venha a ser formalizado. Trata-se de um "núcleo rígido" chamado de devido processo legal ou, nas palavras de Calmon, devido processo constitucional de produção jurisdicional do direito ${ }^{7}$.

Nessa ótica, o que se afigura importante "é verificar se no procedimento, seja ele qual for, o essencial a todo processo jurisdicional foi atendido". Em outras palavras, o que importa saber, utilizando a linguagem do garantismo processual/garantística, é se o procedimento

\footnotetext{
${ }^{6}$ CALMON DE PASSOS, José Joaquim. Teoria geral dos procedimentos especiais. In: CALMON DE PASOS, José Joaquim. Ensaios e artigos. Organizadores Fredie Didier J. e Paula Sarno Braga. Salvador: Juspodivim, 2016, p. 205-206.

${ }^{7}$ CALMON DE PASSOS, José Joaquim. Teoria geral dos procedimentos especiais. In: CALMON DE PASOS, José Joaquim. Ensaios e artigos. Organizadores Fredie Didier J. e Paula Sarno Braga. Salvador: Juspodivim, 2016, p. 206.
} 
instituído previamente pelo legislador corporifica o direito fundamental ao devido processo legal ou se, ao contrário, estabelece limitações ao devido processo legal que não sejam constitucionalmente justificáveis. Por isso, para Calmon, "o procedimento ordinário é o que traduz o excelente para a quase totalidade dos processos", devendo ser avaliadas criticamente as eventuais mudanças simplificadoras que se revelem necessárias e possíveis, sem sacrifício do que é a essência do processo jurisdicional ${ }^{8}$.

Com efeito, Calmon era um cético em relação aos procedimentos especiais. Enxergava neles um elemento tendente a criar desigualdades e complicações, acobertando tratamentos privilegiados ${ }^{9}$. De fato, essa é uma crítica recorrente aos procedimentos especiais, que se apresenta em diferentes setores dogmáticos, embora, metodologicamente, essa crítica muitas vezes nem mesmo é objeto da dogmática jurídica, mas da política ${ }^{10}$. Afirma-se, nesse sentido, que os procedimentos especiais comumente representam um fator de desigualdade, na medida em que alguns direitos recebem tratamento privilegiado, com proteção mais eficiente, ficando uma tutela ineficiente reservada ao cidadão comum que não é titular de alguma situação jurídica privilegiada ${ }^{11}$. Deve-se registrar que uma grande celeuma que surge aqui é a de determinar quais causas serão submetidas a um procedimento especial e, portanto, a um procedimento melhor e mais adequado à tipologia do direito material. Tecnicamente, a instituição de procedimentos especiais deveria estar atrelada "à natureza, à feição e à estrutura peculiar de determinados direitos substanciais" ${ }^{12}$. Dito de outro modo, a escolha das causas submetidas aos procedimentos especiais estaria relacionada ao próprio direito material ${ }^{13}$. No entanto, isso nem sempre acontece. Muitas

\footnotetext{
${ }^{8}$ CALMON DE PASSOS, José Joaquim. Teoria geral dos procedimentos especiais. In: CALMON DE PASOS, José Joaquim. Ensaios e artigos. Organizadores Fredie Didier J. e Paula Sarno Braga. Salvador: Juspodivim, 2016, p. 206-207.

${ }^{9}$ CALMON DE PASSOS, José Joaquim. Teoria geral dos procedimentos especiais. In: CALMON DE PASOS, José Joaquim. Ensaios e artigos. Organizadores Fredie Didier J. e Paula Sarno Braga. Salvador: Juspodivim, 2016, p. 207.

10 Sobre os objetos e metodologia de uma dogmática jurídica, ver nossa posição em RAATZ, Igor; ANCHIETA, Natascha; DIETRICH, William Galle. Processualismo científico e "fases metodológicas do processo": a tática erística do adjetivo científico e das "novas fases metodológicas". Revista eletrônica de direito processual, v. 21, p. 296-327, 2020.

${ }^{11}$ TARUFFO, Michelle. Razionalità e crisi della legge processuale. Sui confini: scriti sulla giustizia civile. Bologna: Il Mulino, 2002, p. 53.

${ }^{12}$ MARCATO, Antonio Carlos. Procedimentos especiais. 8. ed. São Paulo: Malheiro, 1998, p. 38.

${ }^{13}$ FABRÍCIO, Adroaldo Furtado. Justificação teórica dos procedimentos especiais. In: FABRÍCIO, Adroaldo Furtado. Ensaios de direito processual. Rio de Janeiro: Forense, 2003, p. 38.
} 
Revista Eletrônica de Direito Processual - REDP.

Rio de Janeiro. Ano 15. Volume 22. Número 2. Maio a Agosto de 2021

Periódico Quadrimestral da Pós-Graduação Stricto Sensu em Direito Processual da UERJ

Patrono: José Carlos Barbosa Moreira (in mem.). ISSN 1982-7636. pp. 405-433

www.redp.uerj.br

vezes o legislador se apega ao peso da tradição histórica, a circunstâncias momentâneas ${ }^{14}$, valendo-se do seu "supremo arbítrio" 15 para alocar, injustificadamente, certas causas aos procedimentos especiais, muitas vezes por razões econômicas e ideológicas (ficando, nesse ponto, bastante claro que a disputa desses argumentos geralmente situa-se fora da arena estritamente dogmática) ${ }^{16}$. Esse fator de desigualdade presente nos procedimentos especiais levou Ovídio A. Baptista da Silva a chamá-los de "processos privilegiados" e a visualizar a formação de dois sistemas processuais, "um popular, plebeu, para aqueles que não disponham de um procedimento privilegiado" e outro "destinado a tutelar as várias estruturas de Poder, visível e invisível"17.

Mas não é só isso. Calmon soube como poucos apontar que a especialização reclamada pelo direito material não residiria propriamente no procedimento tal qual

\footnotetext{
${ }^{14}$ Conforme Adroaldo Furtado Fabrício, “a verdade, pois, é que os legisladores não se orientam apenas por aquela diretriz. O peso da tradição histórica, com as complicações e incongruências decorrentes de múltiplas fontes de influência, bem sempre coevas e coerentes; a eventual interpenetração, o mesmo processo, de elementos de diversas modalidades de tutela jurisdicional (de cognição, de execução e cautelar); razões de conveniência momentânea e local, com caráter meramente emergencial; até mesmo a simples impaciência do legislador frente à morosidade do aparelhamento judiciário em contraste com a pressão da necessidade social - tudo influi no sentido de retirar da "vala comum" do rito ordinário um número crescente de "ações", em antagonismo com as recomendações da doutrina, está cada vez mais inclinada à redução numérica dos tipos procedimentais como imperativo da simplificação e da racionalização" (FABRÍCIO, Adroaldo Furtado.
} Comentários ao código de processo civil. v. VIII, tomo III: arts. 890 a 945. Rio de Janeiro: Forense, 2008, p. 8).

${ }^{15}$ Chega-se ao ponto de afirmar que "a escolha dos casos para que se estabelece processo especial, bem como o seu organismo, baseia-se, mais ou menos, em critérios de conveniência e de oportunidade prática, de que o legislador é árbitro supremo, e por isso não somente entre os códigos das diferentes nações e na mesma nação aparecem depois dos códigos diferentes processos especiaes avulsos, mas nos mesmos códigos nota0se uma grande diversidade de fórmas" (SILVA, Manuel Dias da. Processos civis especiais. 2. ed. revista e actualizada pelo professor José Alberto dos Reis. Coimbra: França Amado, 1919, p. 16-17). Também no sentido de que "são, portanto, razões de conveniência política que traçam a especialidade de determinados procedimentos para o exercício da função jurisdicional à luz de determinadas situações de direito material conflituoso e outras não", ver BUENO, Cassio Scarpinella. Curso sistematizado de direito processual civil. v.1: teoria geral do direito processual civil. $8^{\text {a }}$ ed. São Paulo: Saraiva, 2013, p. 424.

${ }^{16} \mathrm{O}$ viés ideológico dos procedimentos especiais foi duramente criticado por Carlos Alberto Alvaro de Oliveira, segundo o qual "enquanto o comum dos mortais há de se contentar com o moroso e pouco eficiente procedimento comum; enquanto o pobre mortal, ou melhor, o mortal pobre, vê-se forçado ao procedimento sumaríssimo (muitíssimo ordinário, por sinal, segundo a conhecida 'blague' de J.J. Calmon de Passos), os donos do Poder estão a salvo dessas mazelas, reinando sobranceiros no Olimpo! As contendas mais sensíveis, que ponham em jogo os valores de maior interesse para as classes dominantes, essas escapam ao rito demorado e ineficiente, prolongado e desastroso. Para esses litígios criaram-se, simplesmente, procedimentos especialíssimos, geralmente com total desconhecimento de tão decantando princípio da igualdade das partes no processo, gerando-se, com isso, dupla desigualdade: desigualdade de procedimento e desigualdade no procedimento (ALVARO DE OLIVEIRA, Carlos Alberto. Procedimento e ideologia no direito brasileiro atual. In: TUBENCHLAK, James, 1939- (coord.). Livro de estudos jurídicos. v. 4. Rio de Janeiro: Instituto de Estudos Jurídicos, 1991, p. 183).

${ }^{17}$ SILVA, Ovídio A. Baptista da. Processo e ideologia: o paradigma racionalista. Rio de Janeiro: Forense, 2004, p. 162. 
propugnado pelos defensores dos procedimentos especiais e, atualmente, pelos entusiastas da flexibilização procedimental pelo juiz. Conforme o professor baiano, "o que reclama tratamento diferenciado, em verdade, porque necessariamente diferenciada, é a efetivação da tutela jurídica certificada como devida pela tutela jurisdicional". Por isso, "o que se especializa é o momento satisfativo do procedimento", de modo que a "a única especialidade pensável será neste nível - no da efetivação da decisão, vale dizer, no da efetividade da tutela jurídica certificada como devida pela tutela jurisdicional ${ }^{\prime \prime 18}$.

O discurso em favor dos procedimentos especiais se desenvolveu a partir da noção de adequação objetiva, ou seja, das relações entre o procedimento e o direito material ${ }^{19}$, mediante a pretensão de adequar a tutela jurisdicional às exigências particulares das diversas situações nas quais deve operar ${ }^{20}$, de modo a atender à maior aderência dos mecanismos procedimentais às características de cada direito material e a promover o direito fundamental à igualdade ${ }^{21}$. Consequentemente, ao lado do procedimento comum ordinário - da noção de um procedimento comum a todos as causas ${ }^{22}$-, que constitui a regra geral, gradualmente foram sendo criados pelo legislador outros procedimentos, que, por fugirem em diversos aspectos da estrutura do procedimento ordinário, receberam o nome de procedimentos especiais $^{23}$. A ideia corrente, nessa matéria, sempre foi a inicial definição de um modelo procedimental básico, destinado à generalidade dos casos, e, posteriormente, a instituição de acréscimos, supressões ou modificações de atos para que se fossem construídos outros procedimentos $^{24}$. Tais procedimentos, abstratamente previstos em lei, serviriam para

18 CALMON DE PASSOS, José Joaquim. Teoria geral dos procedimentos especiais. In: CALMON DE PASOS, José Joaquim. Ensaios e artigos. Organizadores Fredie Didier J. e Paula Sarno Braga. Salvador: Juspodivim, 2016, p. 208-209.

${ }^{19}$ LACERDA, Galeno. O Código como Sistema legal de adequação do processo. In: Revista do instituto dos advogados do Rio Grande do Sul - Comemorativa do Cinqüentenário. Porto Alegre: IARGS, 1976, p. 164.

20 TROCKER, Nicolò. Processo civile e costituzione: problemi di diritto tedesco e italiano. Milano: Giuffrè, 1974 , p. 701.

${ }^{21}$ SILVA. Ovídio A. Baptista da. A "plenitude de defesa" no processo civil. In: Da sentença liminar à nulidade da sentença. Rio de Janeiro: Forense, 2002, p. 126.

${ }^{22}$ Nesse sentido a clássica lição de Manuel Dias da Silva: "processo comum é o que se aplica à generalidade das causas, à defesa judicial de qualquer direito não expressamente exceptuado por lei; processo especial, ou antes processos especiaes são os que se destinam à defesa judicial de certos e determinados direitos expressamente designados por lei" (SILVA, Manuel Dias da. Processos civis especiais. 2. ed. revista e actualizada pelo professor José Alberto dos Reis. Coimbra: França Amado, 1919, p. 14).

${ }^{23}$ Para uma profunda análise histórica do surgimento dos procedimentos especiais, ver LEONEL, Ricardo de Barros. Tutela jurisdicional diferenciada. São Paulo: Revista dos Tribunais, 2010, p. 28-46.

${ }^{24}$ FABRÍCIO, Adroaldo Furtado. Comentários ao código de processo civil. v. VIII, tomo III: arts. 890 a 945. Rio de Janeiro: Forense, 2008, p. 6. 
promover uma maior adequação do processo à situação de direito material, na medida em que instituídos de modo específico e individualizado para o trato de determinadas causas ${ }^{25}$. Contudo, até hoje não se obteve consenso teórico acerca dos elementos que fazem com que um procedimento específico - construído a partir da base estrutural do procedimento ordinário, mas como determinados peculiaridades - seja realmente caracterizado como um procedimento especial. Desse modo, ao admitir-se que qualquer procedimento que possua diferenças em relação ao procedimento comum, por mais sensíveis que sejam, possa ser considerado como um procedimento especial, chancelar-se-ia a tese de Calmon acerca da inexistência de uma teoria geral dos procedimentos especiais.

Ovídio A. Baptista da Silva visualiza, na grande maioria dos procedimentos especiais, modalidades de "processos materialmente sumários" ${ }^{26}$, ou seja, de procedimentos nos quais seriam deduzíveis ações sumárias, abarcando-se, nesse sentido, diferentes possibilidades de limitação da cognição, tanto no plano horizontal, quanto do plano vertical. Contudo, em que pese se trate de uma característica recorrente em procedimentos especiais, a questão relativa à amplitude e à profundidade da cognição pode ser considerada um dado apenas acidental nos ritos especiais, razão pela qual alguns autores defendem que, mesmo em procedimentos especiais, a cognição seja, em regra, plena ${ }^{27}$. Diante disso, há quem prefira adotar uma diferenciação terminológica entre procedimentos especiais e tutelas jurisdicionais diferenciadas, como é o caso de Ricardo de Barros Leonel, para quem o critério da "limitação da cognição realizada pelo magistrado no processo" é o único efetivamente adequado para a construção do conceito de tutela jurisdicional diferenciada ${ }^{28}$. Isso, porém, faz com que a noção de procedimento especial continue limitada à existência de peculiaridades, quaisquer que sejam, capaz de tornar o procedimento instituído pelo legislador em alguma medida diferente do esquema procedimental comum. Por outro lado, o termo "tutela jurisdicional diferenciada" também parece insatisfatório quando encarado

\footnotetext{
${ }^{25}$ FABRÍCIO, Adroaldo Furtado. Justificação teórica dos procedimentos especiais. In: FABRÍCIO, Adroaldo Furtado. Ensaios de direito processual. Rio de Janeiro: Forense, 2003, p. 38.

${ }^{26}$ Nesse sentido, SILVA, Ovídio A. Baptista da. Procedimentos especiais. 2. ed. Rio de Janeiro: Aide, 1993, passim. SILVA, Ovídio A. Baptista da. Curso de processo civil. v.1. 7. ed. Rio de Janeiro: Forense, 2005, p. 101-120.

${ }^{27}$ FABRÍCIO, Adroaldo Furtado. Comentários ao código de processo civil. v. VIII, tomo III: arts. 890 a 945. Rio de Janeiro: Forense, 2008, p. 7.

${ }^{28}$ LEONEL, Ricardo de Barros. Tutela jurisdicional diferenciada. São Paulo: Revista dos Tribunais, 2010, p. 78.
} 
pela ótica da sumariedade da cognição, na medida em que o procedimento civil brasileiro possui um mecanismo genérico - presente no procedimento comum - capaz de permitir a concessão de tutelas de cognição sumária que é a antecipação da tutela.

Tudo isso faz com que, partindo das lições de Calmon de Passos, possamos assentar as seguintes ideias. Em primeiro lugar, a especialização do procedimento comum se dá, num plano macro, de acordo com o direito material, forjando diferentes ramos procedimentais (civil, penal, trabalhista, eleitoral, etc.). Não por acaso, a noção de procedimento comum perpassa os diferentes âmbitos procedimentais, bem como a caracterização do procedimento mediante atos de postulação, instrução, decisão e efetivação, observando-se, em qualquer âmbito, as normas constitucionais que caracterizam o devido processo legal. Em segundo lugar, no plano específico de cada ramo procedimental, é possível a especialização do procedimento frente às peculiaridades do direito material. Porém, essas particularidades procedimentais, construídas a partir de adaptações do procedimento comum em razão do direito material devem ser excepcionais. Nesse âmbito, afora o já apontado problema da transformação dos procedimentos especiais em procedimentos privilegiados em desabono à garantia da igualdade, há, ainda, o risco de que a desmedida proliferação de procedimentos especiais chegar ao ponto de transformar o procedimento ordinário um procedimento residual $^{29}$. Em terceiro lugar, as equivocadamente denominadas relações entre "processo e direito material" devem ser compreendidas como relações entre o direito fundamental à tutela jurisdicional, o direito material e a tutela jurisdicional prestada pelo Estado ao exercer a jurisdição - encarada como um serviço que o Estado presta ao cidadão ${ }^{30}$.

Com efeito, os imperativos de adaptabilidade relacionam-se mais diretamente à própria tutela jurisdicional prestada pelo Estado do que ao procedimento. Por isso, como muito bem posto por Calmon de Passos, o "qualificativo de especial se dá, em verdade, na quase totalidade dos casos, em virtude da natureza da tutela jurídica a ser efetivada, vale dizer, em termos de satisfação e não de certificação", tratando-se de "problema muito mais

${ }^{29}$ CARRATA, Antônio. La "semplificazioni" dei riti e le nuove modifiche del processo civile. Torino: Giappichelli, 2012, p. 10. DONZELLI, Romulo, La fase preliminare del nuovo processo civile inglese e l'attività di "case management" giudiziale. Revista da faculdade de direito do sul de minas. Pouso Alegre, a. XXIV, n. 24, jan-jun/2007, p. 41.

${ }^{30}$ CIPRIANI, Franco. Il processo civile nello Stato democrático. Il processo civile nello Stato democratico. Saggi. Napoli: Edizioni Scientifiche Italiane, 2006, p. 14. 
de pressupostos de direito material que de procedimento"31. E, nesse âmbito específico, as possibilidades de adaptação da tutela jurisdicional devem - sem nunca deixar de levar em consideração a natureza da ação de direito material posta em causa e a tutela jurídica a ser efetivada - ser estabelecidas em lei, cumprindo à dogmática jurídica demarcá-las, ao invés de estabelecer mecanismos para liberar o exercente do poder jurisdicional dos limites que lhe foram impostos para proteção da liberdade individual.

Reconhecer essas possibilidades, contudo, não significa admitir que o procedimento estabelecido em lei é um procedimento maleável e sujeito a adaptações por parte do órgão jurisdicional. Alguns exemplos, nesse âmbito, são bastante elucidativos e nos auxiliam a explicar o tema.

O primeiro exemplo é o direito da parte de obter a concessão da antecipação da tutela jurisdicional pretendida, a partir de um provimento de cognição sumária, quando presentes os requisitos previstos em lei. Por óbvio que, diante da utilização de termos vagos como "probabilidade do direito" e "perigo de dano ou risco ao resultado útil do processo" por parte do legislador (art. 300, CPC), confere-se ao órgão julgador maiores possibilidades de adaptação da tutela jurisdicional às circunstâncias do caso concreto. Dito de outro modo, o legislador, aqui, não estabelece quais as situações de urgência que autorizam à concessão da tutela antecipada. Assim, se por um lado cabe à dogmática jurídica estabelecer os contornos jurídicos tendentes à limitar a atuação do juiz nesse âmbito, é inegável que ocorre uma maior possibilidade de adaptação da tutela jurisdicional às diferentes situações concretas em que se reclama a satisfação do direito material diante de situações de urgência. Por sinal, o caso da tutela antecipada é oposto ao da tutela da evidência, prevista no art. 311 do CPC. Tivesse o legislador permitido que a tutela da evidência fosse concedida nos casos em que o órgão julgador reputasse "evidente o direito do autor", caberia à doutrina buscar parâmetros para estabelecer o que é evidência diante do caso concreto, o que, ainda assim, não retiraria do juiz um maior poder de adaptação da tutela jurisdicional ao caso concreto. Todavia, o legislador brasileiro optou por delimitar, nos quatro incisos do art. 311 do CPC, os casos de evidência do direito do autor a autorizar a concessão da "tutela da evidência", diminuindo os poderes de adaptação da tutela jurisdicional neste caso.

${ }^{31}$ CALMON DE PASSOS, José Joaquim. Teoria geral dos procedimentos especiais. In: CALMON DE PASOS, José Joaquim. Ensaios e artigos. Organizadores Fredie Didier J. e Paula Sarno Braga. Salvador: Juspodivim, 2016, p. 210. 
O segundo exemplo é o do art. 356 do CPC, que permite o julgamento antecipado parcial do mérito da causa quando um ou mais pedidos formulados ou parcela deles $(i)$ mostrar-se incontroverso ou (ii) estiver em condições de imediato julgamento, nos termos do art. 355 do CPC. Novamente, aqui, o dispositivo regula as possibilidades relativas à tutela jurisdicional prestada pelo Estado ao indivíduo mediante limites bem demarcados. Não se trata, pois, de adaptação ou flexibilização do procedimento. Pelo contrário, o procedimento segue dentro de limites previamente estabelecidos em lei, assim como os próprios limites da tutela jurisdicional prestada pelo Estado-juiz.

O terceiro exemplo é o art. 139, IV, do CPC, segundo o qual incumbe ao juiz "determinar todas as medidas indutivas, coercitivas, mandamentais ou sub-rogatórias necessárias para assegurar o cumprimento de ordem judicial, inclusive nas ações que tenham por objeto prestação pecuniária”. O artigo não trata de flexibilização ou adaptação do procedimento, mas dos poderes de efetivação da tutela jurisdicional. Diante da redação confusa do referido texto normativo, o papel da dogmática jurídica consiste em delimitar os poderes que o dispositivo em questão confere ao juiz, tendo por base algumas premissas como é o caso da tutela jurídica conferida ao direito material. No ponto, a leitura corrente, no sentido de enxergar a partir do art. 139, IV, do CPC a possibilidade de concessão de medidas indutivas para a satisfação de obrigações de pagar quantia, esbarra nas especificidades do próprio direito material e na relação de adequação da tutela jurisdicional ao direito material, na medida em que, por força da garantia da responsabilidade patrimonial (art. 391, CC e 789, CPC) a tutela jurisdicional no âmbito das obrigações pecuniárias deve recair sobre o patrimônio do devedor, e não sobre a sua vontade.

Nenhum dos casos previamente referidos trata de flexibilidade procedimental. Em nenhum deles a adaptabilidade da tutela jurisdicional às características do direito material $\mathrm{e}$ do modo como ele se apresenta diante do caso concreto deve ocorrer fora dos estritos limites da legalidade. É bem verdade que os exemplos mencionados evidenciam que a legislação procedimental brasileira admite que a tutela jurisdicional seja maleável às necessidades do caso concreto, porém nada disso significa uma carta branca para que o magistrado venha a assenhorar-se do procedimento. Justamente nessas situações que o papel da dogmática jurídica consiste em estabelecer os contornos para o exercício do poder. Isso não significa descaso como o direito à tutela jurisdicional. Do contrário, se estaria a repetir o que já foi 
advertido por Calmon de Passos: "propugna-se o aumento cada vez maior de poderes para o magistrado, mas se exorciza qualquer discussão sobre sua legitimação democrática e sobre como se assegurar a sociedade contra seus abusos e desvios"32.

\section{Da injustificada flexibilização do procedimento pelo juiz a partir das críticas doutrinárias realizadas à "ordinariedade"}

Ao contrário de Calmon de Passos, alguns autores procuraram estabelecer duras críticas ao procedimento ordinário nos moldes em que foi concebido pelo Código de Processo Civil de 1973. Dentre as críticas mais robustas, pode-se mencionar a doutrina de Ovídio A. Baptista da Silva. Para o professor gaúcho, a universalização do procedimento ordinário, concebido "como a única forma de tutela processual compatível com os valores e padrões culturais da civilização moderna" ${ }^{33}$ seria um dos pilares da neutralidade do processo (leia-se, do procedimento e da tutela jurisdicional) em relação ao direito material. Referido procedimento, na medida em que estruturado para abarcar toda e qualquer situação de direito material, estaria marcado por algumas características como um modelo de cognição plena e exauriente, o contraditório prévio ${ }^{34}$ e uma pseudo-economia processual ${ }^{35}$. É bem verdade que, seguindo a doutrina de Ovídio, afirmou-se que o procedimento ordinário era vocacionado a atingir o ideal de segurança jurídica e que, portanto, deverá ser rígido e

${ }^{32}$ CALMON DE PASSOS, José Joaquim. Teoria geral dos procedimentos especiais. In: CALMON DE PASOS, José Joaquim. Ensaios e artigos. Organizadores Fredie Didier J. e Paula Sarno Braga. Salvador: Juspodivim, 2016, p. 212.

${ }^{33}$ SILVA, Ovídio A. Baptista da. Curso de processo civil. v.1. $7^{\text {a }}$ ed. Rio de Janeiro: Forense, 2005, p. 103.

${ }^{34}$ SILVA, Ovídio A. Baptista da. Processo e ideologia: o paradigma racionalista. Rio de Janeiro: Forense, 2004, p. 155.

${ }^{35}$ Segundo Ovídio, “em geral, imagina-se que o princípio da economia processual seja uma arma contra a morosidade processual, quando, na verdade, ele contribui para que os processos se tornem mais lentos" (...) $\mathrm{Na}$ verdade, quem pretende fazer economia é o Estado, obrigando a que as partes controvertam logo, num único processo, tanto a causa principal quanto aquelas que lhe estariam ligadas por algum vínculo de conexão ou dependência (...) Para obter essa economia, o Estado dilata, até onde pode, as dimensões tanto objetivas quanto subjetivas da causa originária, estimulando, de um lado, as cumulações de duas ou mais lides, mesmo que elas não guardem entre si nenhum parentesco objetivo; e de outro, estimulando os litisconsórcios e intervenções de terceiros, de tal modo que a lide, já pressuposta em si mesma plenária, seja sobrecarregada com o peso, às vezes insuportável, das demandas a ela acrescidas. O resultado disso tudo, como fator de morosidade processual, pode ser facilmente avaliado" (SILVA, Ovídio A. Baptista da. Processo e ideologia: o paradigma racionalista. Rio de Janeiro: Forense, 2004, pp. 162-164). 
inflexível ${ }^{36}$. Contudo, deve-se observar que a crítica central que Ovídio estabeleceu à chamada "ordinariedade" residia na rejeição das tutelas jurisdicionais de cognição sumária e à noção de verdade apodítica e do modo de pensar geométrico no Direito, um legado, segundo ele, do racionalismo para o direito processual moderno.

Considerando que as críticas de Ovídio A. Baptista da Silva à ordinariedade não residiam na impossibilidade de que o juiz pudesse flexibilizar o procedimento, mas, sim, no desprezo à sumariedade material, torna-se possível compreender que, no Brasil, repete-se o mesmo equívoco ocorrido na Itália a partir da difusão do termo "tutelas jurisdicionais diferenciadas" decorrente de um ensaio de Andrea Proto Pisani, publicado na década de 70, no contexto das reformas legislativas pertinentes ao "processo do trabalho", cuja importância política era bastante significativa. Basicamente, duas eram as perspectivas que levaram Proto Pisani a se debruçar sobre o tema das tutelas diferenciadas, inicialmente em um ensaio publicado em 1973 37 . Por um lado, Pisani defendia a constitucionalidade do novo procedimento para a tutela das relações laborais surgido com a Lei 533/73, o qual era pautado pela oralidade e pela concentração dos atos processuais, sendo, desse modo, capaz de conferir uma tutela jurisdicional mais rápida e efetiva aos trabalhadores se comparado ao procedimento ordinário de cognição plena. Por outro lado, a Lei 300/70 havia instituído uma tutela sumária para a repressão da conduta anti-sindical, que constituía a primeira intervenção do legislador republicano com vistas a munir com uma tutela jurisdicional efetiva um direito de liberdade, no caso, o direito de liberdade de associação sindical ${ }^{38}$.

As duas situações tratadas por Proto Pisani sob o nomen juris "tutela jurisdicional diferenciada" eram tecnicamente distintas, o que, no entanto, passou despercebido pela maioria da doutrina, como reconheceu posteriormente o próprio jurista italiano. Na verdade, a primeira situação versava sobre um rito especial de cognição plena (caracterizado pela noção de sumariedade formal), enquanto a segunda dizia respeito a um processo de cognição sumária não cautelar desatrelado do requisito do periculum in mora e voltado à tutela do

${ }^{36}$ SALDANHA, Jânia Maria Lopes. Substancialização e efetividade do direito processual civil - a sumariedade material da jurisdição: proposta de estabilização da tutela antecipada em relação ao projeto do novo CPC. Curitiba: Juruá, 2011, p. 191.

${ }^{37}$ Trata-se do artigo Tutela giurisdizionale differenziata e nuovo processo del lavoro, publicado na revista Foro italiano, v. 205.

${ }^{38}$ PROTO PISANI, Andrea. Dai riti speciali ala differenziazione del rito ordinario. Il foro italiano. Roma: Il foro italiano, 2006, p. 85-86. 
direito à liberdade ${ }^{39}$. Posteriormente, em 1979, Pisani buscou deixar claro a equivocidade do termo "tutela jurisdicional diferenciada", advertindo que, entendida literalmente, a expressão conduziria a uma obviedade, qual seja a de que "a bisogni diversi di tutela devono corrispondere forme diverse di tutela" ${ }^{40}$. No entanto, é possível encontrar no referido ensaio duas acepções para a expressão tutela jurisdicional diferenciada, de modo que uma coisa é a tutela jurisdicional diferenciada como a predisposição de mais procedimentos de cognição plena e exauriente alguns dos quais modelados sob peculiaridades de determinadas situações de direito material (o que seria o equivalente à noção abrangente de procedimento especial do direito brasileiro); outra coisa é a tutela jurisdicional diferenciada como a predisposição de formas típicas de tutela sumária, seja de natureza cautelar, seja de natureza satisfativa ${ }^{41}$. Isso significa que, nas lições iniciais de Proto Pisani, tanto os procedimentos especiais quanto as formas de tutela materialmente sumária estariam enquadrados no conceito de "tutela jurisdicional diferenciada".

Porém, a ênfase que o jurista italiano objetivava conceder era para a segunda situação, vale dizer, à sumariedade material, e não à construção de ritos especiais de cognição plena. Tanto é assim que, em ensaio publicado em 2006, Pisani assume a culpa por não ter, na década de 70, evidenciado com o máximo de clareza a diferença - o "fosso", como diz ele - que se coloca entre os ritos especiais de cognição plena e os processos sumários (= de cognição sumária) não cautelares. Com isso, ele pretende atacar a proliferação de procedimentos especiais de cognição plena, os quais, para ele, cresceram muito em razão da lentidão do procedimento ordinário ${ }^{42}$. Nessa perspectiva, a expressão tutela jurisdicional diferenciada, em que pese no Brasil muitas vezes seja adotada em termos larguíssimos para designar tudo que não é "ordinário" "43, encontra, na linha das mais recentes lições de Proto Pisani, uma significação mais restrita, como sinônimo de tutela de cognição sumária.

\footnotetext{
${ }^{39}$ PROTO PISANI, Andrea. Dai riti speciali ala differenziazione del rito ordinario. Il foro italiano. Roma: Il foro italiano, 2006, p. 86.

${ }^{40}$ PROTO PISANI, Andrea. Sulla tutela giurisdizionale differenziata. Rivista di diritto processuale, n. 4, Padova: Cedam, 1979, p. 537-538.

${ }^{41}$ PROTO PISANI, Andrea. Sulla tutela giurisdizionale differenziata. Rivista di diritto processuale, n. 4, Padova: Cedam, 1979, p. 538.

${ }^{42}$ PROTO PISANI, Andrea. Dai riti speciali ala differenziazione del rito ordinario. Il foro italiano. Roma: Il foro italiano, 2006, p. 86.

${ }^{43}$ WAMBIER, Luiz Rodrigues; WAMBIER, Teresa Arruda Alvim. Tutela diferenciada. Revista de processo, v.35, n.180, fev. 2010. São Paulo: Revista dos Tribunais, 2010, p. $42-54$.
} 
Tudo isso é bastante esclarecedor se considerarmos que boa parte das críticas outrora realizadas ao procedimento ordinário vem sendo utilizadas como justificativa para a defesa da flexibilização do procedimento pelo juiz. Nem mesmo um autor como Ovídio A. Baptista da Silva, cuja obra é marcada pela crítica à ordinariedade, defendeu um modelo procedimental flexível e maleável pelo juiz. As críticas de Ovídio residiam justamente no modo como as ações (de direito material) sumária eram desconsideradas pela legislação brasileira e pela doutrina, que insistia em atrelar a satisfação do direito à declaração com força de coisa julgada. Atualmente, Ovídio provavelmente criticaria posições doutrinárias no sentido de que, com base no art. 304 do CPC, a estabilização da tutela antecipada poderia ser impedida por qualquer manifestação do réu, por considerá-las caudatárias da ordinariedade. Por sinal, é interessante que muitos dos autores que realizam esse tipo de leitura do art. 304 do $\mathrm{CPC}$, critiquem o antigo paradigma do procedimento ordinário, defendendo uma ampla flexibilização do procedimento pelo juiz. Dito de outro modo, criticam aquilo que Ovídio chamou de ordinariedade e repetem aquilo que o próprio Ovídio criticava como sendo o cerne da "ordinariedade".

Consequentemente, a história parece ser repetir. Assim como na Itália a proliferação dos procedimentos especiais - concebidos como procedimentos em que prestada uma tutela jurisdicional de cognição plena e exauriente, porém distintos do procedimento comum ocorreu por força da reivindicação doutrinária em favor de formas de tutela jurisdicional fundadas em cognição sumária seja no plano horizontal, seja no plano vertical da cognição, no Brasil a defesa da flexibilização do procedimento pelo juiz acontece do mesmo modo. Vale dizer, a defesa da flexibilização do procedimento não representa uma tentativa de superação do desprestígio às formas de tutela jurisdicional de cognição sumária, em que pese, boa parte do discurso do qual ela parte, esteja situado nesse plano. O mais interessante nisso tudo é que, embora seja admissível a delimitação do mérito da causa mediante negócio jurídico processual (art. 357, §2. ${ }^{\circ}, \mathrm{CPC}$ ), com a limitação da cognição judicial no plano horizontal - ponto que, efetivamente, representa uma notável superação daquilo que autores como Ovídio A. Baptista denominavam de "ordinariedade" - referida possibilidade tem sido esquecida pela doutrina, que prefere explorar a concessão de poderes para que o juiz possa simplesmente se desgarrar do procedimento previamente estabelecido em lei. 


\section{A posição do garantismo processual/garantística acerca do tema: ou como a defesa de um procedimento estruturado pela lei ou pelas partes não significa um menosprezo ao direito material}

Uma das principais contribuições da garantística reside na superação da noção de processo como instrumento do poder jurisdicional. A afirmação de que o processo é uma garantia contrajurisdicional e, portanto, responsável por limitar o poder jurisdicional é de extrema importância para possibilitar uma espécie de atualização da dogmática processual ao texto constitucional. Com isso, abre-se o caminho para uma melhor demarcação conceitual entre ação, processo e jurisdição. Nessa perspectiva, superam-se as noções instrumentais de processo que acabavam por absorvê-lo na jurisdição, seja do ponto de vista da realização do direito subjetivo, seja do ponto de vista da realização do direito objetivo. $\mathrm{O}$ processo, portanto, não é instrumento para a realização do direito material afirmado em juízo (direito subjetivo), nem é instrumento para a realização dos escopos do poder jurisdicional (que podem variar entre a realização do direito objetivo e a realização do direito subjetivo) ${ }^{44}$.

Quando se diz que o processo é garantia contrajurisdicional não se está a dizer que o processo é uma garantia do indivíduo oponível ao Estado/juiz diante de uma violação ou ameaça a um direito. O termo garantia, utilizado pelo garantismo processual brasileiro, deve ser entendido como tutela contra o arbítrio ${ }^{45}$, como proteção do indivíduo contra o exercente do poder diante dos seus possíveis desmandos, arbítrios e excessos. Falar que o

\footnotetext{
${ }^{44}$ Nesse sentido, "sendo o processo reduzido a um mero instrumento que se coloca entre a ação e a jurisdição, porém sem finalidades bem definidas (sem substancialidade), facilmente três possibilidades se apresentaram: (i) o processo é instrumento para o indivíduo buscar do Estado a realização do direito material; (ii) o processo é instrumento para o Estado impor coativamente a aplicação das leis porventura violadas; ou (iii) o processo é, ao mesmo tempo, instrumento para o indivíduo buscar a realização do direito material e instrumento para o Estado impor coativamente a realização das leis. Grosso modo, afirma-se que o processo serve como instrumento para a realização do direito subjetivo (instrumento para a realização do direito material) e como instrumento para a realização do direito objetivo (instrumento do Estado para reparar lesões à ordem jurídica)" (ANCHIETA, Natascha. Em busca da substancialidade constitucional do processo - os percalços do desenvolvimento histórico da ciência processual: da noção instrumental à noção substancial de processo. Empório do direito. Coluna Garantismo Processual, n. 08. Disponível em: <https://emporiododireito.com.br/leitura/8-em-busca-da-substancialidade-constitucional-do-processo-ospercalcos-do-desenvolvimento-historico-da-ciencia-processual-da-nocao-instrumental-a-nocao-substancialde-processo>. Acesso em 27.07.2020).

${ }^{45}$ Sobre o tema, ver COSTA, Eduardo José da Fonseca Costa. Garantia: dois sentidos, duas teorias. Empório do direito. Coluna Garantismo Processual, n. 44. Disponível em $<$ https://emporiododireito.com.br/leitura/44-garantia-dois-sentidos-duas-teorias>. Acesso em 25.07.2020.
} 
processo é garantia, não significa, portanto, garantia de direitos subjetivos específicos. Afinal, cabe à jurisdição, e não ao processo, a realização do direito material.

Por isso, diante de possíveis confusões terminológicas, o enquadramento do processo na categoria dos direitos fundamentais, tendo como perspectiva a teoria liberal dos direitos fundamentais (bürgerlich-liberale Grundrechtstheorie) ${ }^{46}$, parece ser uma alternativa extremamente interessante para a dogmática processual. Essa proposta, não somente serve para pulverizar as confusões conceituais causadas pelo termo garantia, como também permite tomar emprestada para a dogmática processual um conjunto de ferramentas teóricas bastante consolidadas no intuito de estabelecer limites à intervenção estatal no âmbito de liberdade individual, que, ao fim e ao cabo, é o elemento que caracteriza, em sentido lato, a área de proteção do direito fundamental ao devido processo.

No entanto, sendo o processo devido e, portanto, necessário para que ocorra a atuação jurisdicional - que é limitada enquanto exercício de poder pelo direito fundamental ao processo - por óbvio que diferentes estruturas procedimentais podem impactar no modo como se dá o exercício da jurisdição. É importante destacar que cabe à jurisdição certificar a existência do direito material e satisfazer as diferentes pretensões e ações de direito material deduzidas no processo quando a parte formula seu pedido de tutela jurisdicional. Não há, pois, óbice que o legislador crie diferentes procedimentos para que o exercício da função jurisdicional melhor possa atender o direito à tutela jurisdicional. Porém, o procedimento deve traduzir uma estrutura lógica e cronologicamente arquitetada na qual as partes possam exercer seus direitos fundamentais de defesa, evitando, assim, que o exercício do poder jurisdicional redunde em arbítrio. Caso, para atender às necessidades do direito material e ao direito à tutela jurisdicional, o legislador venha a intervir na área de proteção de algum direito fundamental que compõe o devido processo legal, essa intervenção poderá redundar numa violação à Constituição caso não esteja rigorosa e proporcionalmente ${ }^{47}$ justificada.

\footnotetext{
${ }^{46}$ SCHLINK, Bernhard. Liberdade mediante resistência à intervenção estatal: reconstrução da função clássica dos direitos fundamentais. Revista de direito civil contemporâneo, vol. 11. abr-jun. 2017. São Paulo: Revista dos Tribunais, 2017, p. 261. É importante observar que, na GG alemã não há previsão da cláusula do devido processo legal tal qual acontece na Constituição brasileira de 1988, razão pela qual a aproximação proposta, com a teoria liberal dos direitos fundamentais, se dá de modo bastante abrangente.

${ }^{47}$ Sobre a proporcionalidade como "técnica" de controle de intervenções excessivas, ver LAURENTIIS, Lucas Catib. A proporcionalidade no direito constitucional: origem, modelos e reconstrução dogmática. 1. ed. São Paulo: Malheiros, 2017. Para críticas ao uso equivocado da proporcionalidade no Brasil, ver STRECK,
} 
Portanto, se considerarmos que o conteúdo do processo legal (que é devido) passa por uma série de outros direitos fundamentais (por exemplo, direito fundamental à igualdade, direito fundamental ao contraditório, direito fundamental à ampla defesa, direito fundamental à proibição de prova ilícita, direito fundamental à igualdade, direito fundamental à fundamentação das decisões judiciais - artigo 5. ${ }^{\circ}$, caput, I, LV, LVI, artigo 93, IX, CF), constata-se que o legislador não é livre para construir os procedimentos que irão corporificar o devido processo. Conforme já mencionado, o legislador, ao construir procedimentalmente o devido processo, tem, por força da sua vinculação aos direitos fundamentais, o dever de justificar toda e qualquer intervenção na área de proteção dos direitos fundamentais componentes do devido processo. A tarefa legislativa consiste em densificar o devido processo mediante a edificação de procedimentos que deem primazia à liberdade frente à autoridade, estabelecendo situações jurídicas (direitos, faculdades, poderes, ônus, etc.) nas quais se traduz o exercício de direitos fundamentais que compõem o conteúdo do processo devido. A intervenção legislativa - nessa perspectiva, necessária para a concretização do devido processo - é uma intervenção bifronte: de um lado, ela visa a densificar os direitos fundamentais que caracterizam o devido processo; de outro, ela leva em consideração os elementos das diferentes situações de direito material que serão objeto de decisão pelo poder jurisdicional. Daí a classificação dos procedimentos em civil, penal, trabalhista. A diferenciação que ocorre entre esses procedimentos deve-se, exclusivamente, ao direito material a ser tutelado pelo poder jurisdicional, e não à noção de processo, que, do ponto de vista constitucional, é uma só.

Sendo o processo um direito fundamental de resistência - que, ao fim e ao cabo, garante a liberdade do indivíduo em juízo - ele representa uma limitação tanto ao legislador, quanto ao poder jurisdicional, com o qual seu "relacionamento" ocorre de forma mais direta. Isso porque o exercício do poder jurisdicional representa uma constante e imediata intervenção do Estado sobre a liberdade individual, razão pela qual se o processo fosse um instrumento do Estado, as intervenções do poder jurisdicional sobre a esfera de liberdade do indivíduo não teriam limites. Nessa perspectiva, a autoridade estaria sobreposta à liberdade.

Lenio Luiz. Verdade e consenso: constituição, hermenêutica e teorias discursivas. 6. ed. rev. mod. e ampl. São Paulo: Saraiva, 2017, p. 79-83. 
Por sinal, a tutela da liberdade sob a ótica do garantismo processual assume diferente dimensões. Nesse sentido, ela não somente significa autodeterminação no procedimento instituído em lei (liberdade para agir nos limites legais), mas também determinação do próprio procedimento. Nessa linha, a determinação do procedimento pelos próprios indivíduos se dá por duas vias possíveis: a primeira, mais comum, é pela própria lei - pelo parlamento, por representantes eleitos pelo povo; a segunda, ocorre, nos limites da lei, pelo estabelecimento de negócios jurídicos processuais (artigo 190, CPC), constituindo-se o terreno fértil e constitucionalmente possível para que se possa falar em flexibilização do procedimento. Não há uma terceira via. Logo, desvios procedimentais pelo juiz significam uma afronta à liberdade e, portanto, são sinônimos de tirania. Quando o juiz não cumpre o procedimento estabelecido em lei, pratica ato ilegal e viola o direito fundamental ao devido processo legal.

Portanto, a possibilidade de o juiz flexibilizar o procedimento instituído em lei, modificando-o a fim de concretizar o direito à tutela judicial efetiva mediante intervenções na área de proteção de direitos fundamentais componentes do devido processo constitui nítida ilegalidade, não se tratando, pois, de intervenção em direitos fundamentais ainda que sob o pretexto de estar constitucionalmente justificadas. A Constituição fala em devido processo legal, o que reforça uma reserva legal em favor dos direitos fundamentais que lhe são a essência do devido processo. Logo, quando o juiz se desvia do procedimento instituído pelo legislador (ao qual ele está submetido) e tenta reescrevê-lo, há uma ilegalidade. A lei, sob essa perspectiva, é o primeiro elemento de proteção do devido processo. Interferências judiciais na esfera individual fora do âmbito da legalidade constituem atos de puro arbítrio.

Nota-se, desse modo, que o respeito ao procedimento instituído em lei não representa uma indiferença ao direito material. Além disso, conforme referido no item 2, a existência de mecanismos de tutela jurisdicional que permitem certa adaptabilidade às circunstâncias do caso concreto nada tem a ver com flexibilização do procedimento. Aí a importância das já mencionadas lições de Calmon de Passos para evitar confusões. Do mesmo modo, não há como conceber no $2 .^{\circ}$ do art. 327 do CPC uma fonte autorizadora da flexibilização do procedimento pelo juiz. Na verdade, referido dispositivo somente permite que eventuais peculiaridades procedimentais estabelecidas pelo legislador sejam incorporadas ao procedimento comum quando houver cumulação de ações de direito material. Somente isso 
e nada mais! Portanto, ao criticar a flexibilização do procedimento pelo juiz, o que faz a garantística é defender a legalidade e o respeito aos direitos fundamentais, notadamente aqueles que caracterizam o devido processo legal.

\section{A experiência do direito comparado: como a flexibilização procedimental dentro de limites estabelecidos em lei não se confunde com a construção do procedimento pelo juiz}

Não é nosso objetivo realizar, aqui, um juízo crítico acerca das experiências do direito comparado no tocante à temática da flexibilização procedimental e seu comprometimento com o gerencialismo processual $^{48}$ e uma visão liberal-social ou neoliberal de processo, representativa de espécie de "neo-ativismo gerencial"49, cuja marca são os três "es" do New Public Management dos ingleses e do Global Public Management dos americanos: economia, eficiência e efetividade ${ }^{50}$. O que pretendemos ressaltar nas linhas a seguir é que o modelo de flexibilização procedimental adotado tanto na Inglaterra quanto na França passa muito longe da possibilidade de que o juiz possa amoldar o procedimento ao caso concreto sem critérios e limites bastante específicos.

$\mathrm{Na}$ Inglaterra, o estágio final da fase preparatória da causa (que corresponderia ao saneamento e organização do procedimento do art. 357 do CPC brasileiro) é marcada pela "allocation”, que consiste em um dever da autoridade judiciária, que é desenvolvido com base em informações fornecidas pelas partes, mediante uma espécie de questionário

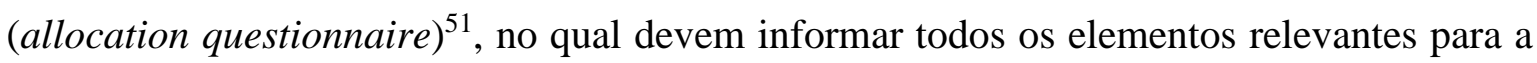

${ }^{48}$ Em artigo emblemático sobre o tema, Judith Resnik aponta uma série de riscos de um juiz seduzido por calendários controlados, estatísticas e outras armadilhas da era da eficiência frente às garantais do devido processo legal. A respeito, ver RESNIK, Judith. Managerial judges. Harvard law review, vol. 96, 1982.

${ }^{49}$ COSTA, Eduardo José da Fonseca. Los criterios de la legitimación jurisdiccional según los activismos socialista facista y gerencial. Revista Brasileira de Direito Processual, n. 82, 2013, p. 205-216.

${ }^{50}$ SPIGELMAN, James. The 'new public management' and the courts. Australian law jornal, vol. 75, 2001. Disponível em: <https://papers.ssrn.com/sol3/papers.cfm?abstract_id=1800452>. Acesso em 26.09.2020.

51 Conforme Gerlis e Loughlin, "the allocation questionnaire consists of 8 sections designed to provide the court with enough information to allocate the claim to a track. The information that a party must provide is as follows: tether a party would like a stay of proceedings in order to attempt to settle the case by ADR or other means; which track the party considers is most suitable for the case (...), whether the party has complied with any applicable pre-action protocol and if not, why not, and if no pre-action protocol applies to the claim whether the party has exchanged information and documents in order to assist in settling the claim; whether the party intends to make any application, for example, for summary judgment or permission to join another party (...), the identity of the party's witnesses of fact and the facts they will give evidence of (...), whether a party would like permission to use expert evidence at trial, and if so whether that should be oral or written 
Revista Eletrônica de Direito Processual - REDP.

Rio de Janeiro. Ano 15. Volume 22. Número 2. Maio a Agosto de 2021

Periódico Quadrimestral da Pós-Graduação Stricto Sensu em Direito Processual da UERJ

Patrono: José Carlos Barbosa Moreira (in mem.). ISSN 1982-7636. pp. 405-433

www.redp.uerj.br

escolha do percurso adequado para a causa ${ }^{52}$, a fim de que seja escolhido o caminho mais adequado para o caso concreto ${ }^{53}$, a saber: o small claims track, o fast track e o multi-track.

De modo geral, a abrangência de cada um dos três management tracks citados é baseada no valor financeiro do pedido ${ }^{54}$. Porém, diversas outras circunstâncias podem ser relevantes para a escolha do percurso mais adequado ao caso concreto, como (a) a natureza do remédio pretendido, (b) a complexidade provável dos fatos, do direito ou das provas, (c) o número de litigantes, (d) a quantidade de provas orais que podem ser exigidas, (e) a importância do crédito para pessoas que não são parte no litígio, (f) as opiniões das partes e (g) as suas circunstâncias ${ }^{55}$. A diversidade ritual prende-se, desse modo, ao ideal de proporcionalidade e de elasticidade, na medida em que as características estruturais de cada controvérsia, notadamente o seu valor e a sua complexidade, tornam-se decisivas para estabelecer o rito mais adequado para resolvê-la ${ }^{56}$.

No direito francês, a semelhança do que ocorre no direito inglês, a fase preparatória do procedimento desenvolve-se no sentido de permitir que se possa, ao seu final, adaptar o processo a um dos três percursos (circuits) possíveis, de acordo com a complexidade da

evidence, if oral the reason why such evidence is necessary and whether the party considers the case suitable for a single joint expert, a figure for the amount of the claim in dispute, whether the party would like the case heard at a court in a particular location (...), an estimate of the length of the trial and trial dates to avoid, an estimate of costs incurred to date and to be incurred, a copy of suggested directions and an indication whether they are agreed, other information which may assist the court to manage the claim" (GERLIS, Stephen M. LOUGHLIN, Paula. Civil procedure. London: Cavendish publishing, 2001, p. 156-157).

${ }^{52}$ FICCARELLI, Beatrice. Fase preparatoria del processo civile e case management giudiziale. Napoli: Edizioni Schientifiche Italiane, 2011, p. 114.

${ }^{53}$ GERLIS, Stephen M. LOUGHLIN, Paula. Civil procedure. London: Cavendish publishing, 2001, p. 157. No entanto, Assim como acontece no procedimento civil brasileiro, é possível que seja designada uma audiência para realizar a alocação da causa a um determinado procedimento (allocation hearing), sempre que for necessário CPR 26.5 (4). Conforme Gerlis e Loughlin, "the circumstances when the court is likely to hold an allocation hearing are if, for example, one of the parties has failed to file an allocation questionnaire or failed to provide further information after being ordered to do so by the court, or if the parties have requested the case be allocated to different tracks and it is no clear which track is the most appropriate" (GERLIS, Stephen M. LOUGHLIN, Paula. Civil procedure. London: Cavendish publishing, 2001, p. 158).

${ }^{54}$ VORASSI, Kenneth M. England's reform to alleviate the problems of civil process: a comparision of judicial case management in England and the United States. Journal of legislation, v. 30: Iss. 2, Article 8. University of Notre Dame, p. $372 . \quad$ Disponível em: <http://scholarship.law.nd.edu/jleg/vol30/iss2/8/?utm_source=scholarship.law.nd.edu $\% 2 F j l e g \% 2 F v o 130 \% 2$ Fiss2\%2F8\&utm_medium=PDF\&utm_campaign=PDFCoverPages $>$. Acesso em 16/06/2015.

${ }^{55}$ CPR $26.8(1)$

56 DONZELLI, Romulo. La fase preliminare del nuovo processo civile inglese e l'attività di "case management" giudiziale. Revista da faculdade de direito do sul de Minas, v. XXIV, n. 24, jan./jun. 2007, p. 28-29. 
Revista Eletrônica de Direito Processual - REDP.

Rio de Janeiro. Ano 15. Volume 22. Número 2. Maio a Agosto de 2021

Periódico Quadrimestral da Pós-Graduação Stricto Sensu em Direito Processual da UERJ

Patrono: José Carlos Barbosa Moreira (in mem.). ISSN 1982-7636. pp. 405-433

www.redp.uerj.br

controvérsia $^{57}$ : o circuit court ou ultracourt, o circuit moyen e o circuit long. A alocação da causa a um desses circuitos é realizada numa audiência preliminar e preparatória, comumente denominada Conférence du Président, em que o presidente da câmara ou seção para qual a causa foi distribuída, examina o seu estado em colaboração com as partes ${ }^{58}$.

Com efeito, caso se verifique, após as explicações dos advogados, e levando em consideração as conclusões apresentadas, que a causa está pronta para julgamento, ou ainda nos casos em que o réu não se defende, o Président considera encerrada a instrução e designa uma audiência para julgamento, que poderá ocorrer ainda no mesmo dia. Trata-se, aqui, do denominado circuit court ${ }^{59}$. Há, porém, um caminho intermediário, chamado circuit moyen, a ser tomado sempre que o juiz entender necessária mais uma audiência - na qual as partes apresentarão novos arrazoados e elementos probatórios - para que a causa esteja madura para julgamento ${ }^{60}$. Por fim, é previsto um circuit long para as causas mais complexas, em que o Président remete o andamento do processo a um juiz instrutor (juge de la mise en état), encarregado de velar pelo andamento leal do processo, estando munido de todos os poderes necessários para tanto ${ }^{61}$.

${ }^{57}$ CADIET, Loïc. Complessità e riforme del processo civile francese. DONDI, Angelo. Elementi per una definizione di complessità processuale. Milano: Giuffrè Editore, 2011, p. 118. O mesmo texto pode se encontrado na rivista trimestrale di diritto e di procedura civile: CADIET, Loïc. Complessità e riforme del processo civile francese. Rivista trimestrale di diritto e procedura civile, v. 62, n.4, p. 1303-1326, dez. 2008. Milano: Giuffrè, 2008, p. 1314-1315.

${ }^{58}$ BONATO, Giovani. I poteri i provvedimenti del juge de la mise en état nel processo civile francese alla luce della riforma del 2004-2005. In: CARRATA, Antonio. La tutela sommaria in europa - studi. Napoli: Jovene Editore, 2012, p. 291. Nesse sentido, prescrevem os parágrafos $1^{\circ}$. e $2^{\circ}$. do art. 759 do Code de procédure civile: Au jour fixé, l'affaire est obligatoirement appelée devant le président de la chambre à laquelle elle a été distribuée. Celui-ci confère de l'état de la cause avec les avocats présents.

${ }^{59}$ Nesse sentido, prescreve o art. 760 do code de procédure civile: "le président renvoie à l'audience les affaires qui, d'après les explications des avocats et au vu des conclusions échangées et des pièces communiquées, lui paraissent prêtes à être jugées sur le fond. Il renvoie également à l'audience les affaires dans lesquelles le défendeur ne comparaît pas si elles sont en état d'être jugées sur le fond, à moins qu'il n'ordonne la réassignation du défendeur. Dans tous ces cas, le président déclare l'instruction close et fixe la date de l'audience. Celle-ci peut être tenue le jour même".

${ }^{60}$ No circuit moyem "continua a non aversi la nomina di un giudice istruttore ed il Presidente, in considerazione della probabile utilità di ulteriori scambi difensivi, alla prima udiena ne fissa una seconda per eventuali repliche sul merito e per la formulazione di nuove istanze istruttorie; ivi la causa viene avviata all'udienza conclusiva, salva la possibilità di un trsaferimento al percorso più articolato ove la controversai si riveli più complessa del previsto" (DE CRISTOFARO, Marco. Case management e riforma del processo civile, tra effettività della giurisdizione e diritto costituzionale al giusto processo. Rivista di diritto processuale, Anno LXV (seconda serie). N. 2. Marzo-Aprile 2010. Padova: CEDAM, 2010, p. 298).

${ }^{61}$ DE CRISTOFARO, Marco. Case management e riforma del processo civile, tra effettività della giurisdizione e diritto costituzionale al giusto processo. Rivista di diritto processuale, Anno LXV (seconda serie). N. 2. Marzo-Aprile 2010. Padova: CEDAM, 2010, p. 298. Nesses termos, dispõe o art. 763 do code de procédure civile: "l'affaire est instruite sous le contrôle d'un magistrat de la chambre à laquelle elle a été distribuée. Celui-ci a mission de veiller au déroulement loyal de la procédure, spécialement à la ponctualité de l'échange 
No Brasil, contudo, a flexibilidade procedimental vem sendo empregada como fórmula transformadora do devido processo legal em indevido processo judicial, desconsiderando o procedimento previamente estabelecido em lei. Há, de início, uma sensível diferença entre o modelo brasileiro e o modelo inglês. O allocation case management inglês não confere ao juiz o poder de criar um procedimento fora da lei, mas, sim, de alocar o caso concreto a procedimentos pré-estabelecidos mediante uma série de critérios objetivos relacionados ao valor, à complexidade e a outros elementos específicos da causa. Adaptabilidade procedimental, no Direito inglês, longe está de ser sinônimo de criatividade procedimental como ocorre no Brasil. Daí que, mesmo para quem considera virtualmente possível a incorporação das técnicas do active case management ao Direito brasileiro, é no mínimo exagerada a defesa de uma "gestão processual eficiente mediante flexibilização procedimento pelo juiz às peculiaridades do caso concreto e às necessidades do direito material" $" 62$.

Por tudo isso que a flexibilização do procedimento deve ser pensada para as partes e pelas partes, dando-se ênfase a sua realização pela via dos negócios jurídicos processuais. A experiência do direito comparado, no ponto, serve principalmente para indicar que novas "rotas procedimentais" devem ser previamente estabelecidas pelo legislador, com a possibilidade de alocação do caso concreto a elas, não se admitido, portanto, que o juiz crie ou flexibilize o procedimento em detrimento de garantias fundamentais das partes.

\section{Considerações finais}

Neste ensaio procuramos mostrar que a clareza com que Calmon de Passos diferenciou a relação entre procedimentos especiais e o direito material dos mecanismos de tutela jurisdicional, voltados à concretização da tutela jurídica conferida ao direito material, afigura-se extremamente importante para evitar as confusões conceituais produzidas na

des conclusions et de la communication des pièces. Il peut entendre les avocats et leur faire toutes communications utiles. Il peut également, si besoin est, leur adresser des injonctions. Il peut ordonner le retrait du rôle dans les cas et conditions des articles 382 et 383 ".

${ }^{62}$ REDONDO, Bruno Garcia. Eficiência da prestação jurisdicional e flexibilização do procedimento pelo juiz e pelas partes. Revista jurídica UNIGRAM, v. 15. n. 30. jul./dez. 2013. Dourados: UNIGRAM, 2013, p. 108. 
doutrina brasileira tanto para defender a flexibilização do procedimento pelo juiz, quanto para acusar o garantismo processual/garantística de indiferença ao direito material.

Em síntese, a adaptabilidade da tutela jurisdicional às circunstâncias do caso concreto e ao direito material nada tem a ver com a adaptação do procedimento pelo juiz. Por outro lado, eventuais construções procedimentais afinadas ao direito material somente são possíveis quando seja considerado que, antes de tudo, o procedimento vem a corporificar o direito fundamental ao devido processo legal. Fora disso, qualquer procedimento especial, por mais bem intencionado que esteja o legislador, representará, em princípio, uma intervenção indevida na área de proteção do direito fundamental previsto no art. 5. ${ }^{\circ}$, LIV , da Constituição Federal. Nada disso significa negar a importância da relação entre o direito à tutela jurisdicional, o procedimento estabelecido em lei, o direito material e a tutela jurisdicional prestada pelo Estado ao cidadão. Porém, é possível, a partir da defesa da efetividade da tutela jurisdicional, inverter a lógica que pauta o direito fundamental ao devido processo e que está consagrada na Constituição, no sentido de colocar sempre a liberdade à frente da autoridade ou, dito de outro modo, o processo à frente do poder jurisdicional.

\section{REFERÊNCIAS}

ALVARO DE OLIVEIRA, Carlos Alberto. Procedimento e ideologia no direito brasileiro atual. In: TUBENCHLAK, James, 1939- (coord.). Livro de estudos jurídicos. v. 4. Rio de Janeiro: Instituto de Estudos Jurídicos, 1991.

ANCHIETA, Natascha. Em busca da substancialidade constitucional do processo - os percalços do desenvolvimento histórico da ciência processual: da noção instrumental à noção substancial de processo. Empório do direito. Coluna Garantismo Processual, n. 08. Disponível em: <https://emporiododireito.com.br/leitura/8-em-busca-dasubstancialidade-constitucional-do-processo-os-percalcos-do-desenvolvimentohistorico-da-ciencia-processual-da-nocao-instrumental-a-nocao-substancial-deprocesso>. Acesso em 27.07.2020.

BONATO, Giovani. I poteri i provvedimenti del juge de la mise en état nel processo civile francese alla luce della riforma del 2004-2005. In: CARRATA, Antonio. La tutela sommaria in europa - studi. Napoli: Jovene Editore, 2012. 
BUENO, Cassio Scarpinella. Curso sistematizado de direito processual civil. v.1: teoria geral do direito processual civil. $8^{\text {a }}$ ed. São Paulo: Saraiva, 2013.

CADIET, Loïc. Complessità e riforme del processo civile francese. DONDI, Angelo. Elementi per una definizione di complessità processuale. Milano: Giuffrè Editore, 2011.

CADIET, Loïc. Complessità e riforme del processo civile francese. Rivista trimestrale di diritto e procedura civile, v. 62, n.4, p. 1303-1326, dez. 2008. Milano: Giuffrè, 2008.

CALMON DE PASSOS, José Joaquim. Teoria geral dos procedimentos especiais. In: CALMON DE PASOS, José Joaquim. Ensaios e artigos. Organizadores Fredie Didier J. e Paula Sarno Braga. Salvador: Juspodivim, 2016.

CARRATA, Antônio. La "semplificazioni" dei riti e le nuove modifiche del processo civile. Torino: Giappichelli, 2012.

CERQUEIRA, Társis Silva de. O procedimento comum e sua relação com os procedimentos especiais: a análise do conteúdo normativo do art. $327, \S 2 .^{\circ}$, do Código de Processo Civil. Salvador: Juspodivm, 2020.

CIPRIANI, Franco. Il processo civile nello Stato democrático. Il processo civile nello Stato democratico. Saggi. Napoli: Edizioni Scientifiche Italiane, 2006.

COSTA, Eduardo José da Fonseca Costa. Garantia: dois sentidos, duas teorias. Empório do direito. Coluna Garantismo Processual, n. 44. Disponível em <https://emporiododireito.com.br/leitura/44-garantia-dois-sentidos-duas-teorias>. Acesso em 25.07.2020.

COSTA, Eduardo José da Fonseca. Garantismo ou garantística. Empório do direito. Coluna Garantismo Processual, n. 78. Disponível em: $<$ https://emporiododireito.com.br/leitura/78-garantismo-ou-garantistica>. Acesso em 05.01.2020.

COSTA, Eduardo José da Fonseca. Los criterios de la legitimación jurisdiccional según los activismos socialista facista y gerencial. Revista Brasileira de Direito Processual, $n$. $82,2013$.

COSTA, Eduardo José da Fonseca. Notas para uma garantística. Empório do direito. Disponível em <http://emporiododireito.com.br/leitura/abdpro-40-notas-para-umagarantistica>. Acesso em 05.07.2018.

COSTA, Eduardo José da Fonseca. O processo como instituição de garantia. Consultor jurídico. 16 de nov. de 2016. Disponível em <https://www.conjur.com.br/2016-nov16/eduardo-jose-costa-processo-instituicao-garantia >. Acesso em 10.05.2020. 
DALLA BARBA, Rafael Giorgio. Se o processo é uma garantia de liberdade, ele é um direito de defesa. Empório do direito. Coluna Garantismo Processual, n. 46. Disponível em: <https://emporiododireito.com.br/leitura/46-se-o-processo-e-umagarantia-de-liberdade-ele-e-um-direito-de-defesa>. Acesso em 05.05.2020.

DE CRISTOFARO, Marco. Case management e riforma del processo civile, tra effettività della giurisdizione e diritto costituzionale al giusto processo. Rivista di diritto processuale, Anno LXV (seconda serie). N. 2. Marzo-Aprile 2010. Padova: CEDAM, 2010 .

DIDIER JR., Fredie; CABRAL, Antônio do Passo; CUNHA, Leonardo Carneiro da. Por uma nova teoria dos procedimentos especiais: dos procedimentos às técnicas. Salvador: Juspodivm, 2018.

DONZELLI, Romulo, La fase preliminare del nuovo processo civile inglese e l'attività di "case management" giudiziale. Revista da faculdade de direito do sul de minas. Pouso Alegre, a. XXIV, n. 24, jan-jun/2007.

FABRÍCIO, Adroaldo Furtado. Comentários ao código de processo civil. v. VIII, tomo III: arts. 890 a 945. Rio de Janeiro: Forense, 2008.

FABRÍCIO, Adroaldo Furtado. Justificação teórica dos procedimentos especiais. In: FABRÍCIO, Adroaldo Furtado. Ensaios de direito processual. Rio de Janeiro: Forense, 2003.

FICCARELLI, Beatrice. Fase preparatoria del processo civile e case management giudiziale. Napoli: Edizioni Schientifiche Italiane, 2011.

GERLIS, Stephen M. LOUGHLIN, Paula. Civil procedure. London: Cavendish publishing, 2001.

LACERDA, Galeno. O Código como Sistema legal de adequação do processo. In: Revista do instituto dos advogados do Rio Grande do Sul - Comemorativa do Cinqüentenário. Porto Alegre: IARGS, 1976.

LAURENTIIS, Lucas Catib. A proporcionalidade no direito constitucional: origem, modelos e reconstrução dogmática. 1. ed. São Paulo: Malheiros, 2017.

LEONEL, Ricardo de Barros. Tutela jurisdicional diferenciada. São Paulo: Revista dos Tribunais, 2010.

MARCATO, Antonio Carlos. Procedimentos especiais. 8. ed. São Paulo: Malheiro, 1998.

PROTO PISANI, Andrea. Dai riti speciali ala differenziazione del rito ordinario. Il foro italiano. Roma: Il foro italiano, 2006. 
RAATZ, Igor. Processo, liberdade e direitos fundamentais. Revista de processo, ano 44. Vol. 288. Fevereiro de 2019. São Paulo: Revista dos Tribunais, 2019.

RAATZ, Igor; ANCHIETA, Natascha; DIETRICH, William Galle. Processualismo científico e "fases metodológicas do processo": a tática erística do adjetivo científico e das "novas fases metodológicas". Revista eletrônica de direito processual, v. 21, p. 296-327, 2020.

REDONDO, Bruno Garcia. Eficiência da prestação jurisdicional e flexibilização do procedimento pelo juiz e pelas partes. Revista jurídica UNIGRAM, v. 15. n. 30. jul./dez. 2013. Dourados: UNIGRAM, 2013.

RESNIK, Judith. Managerial judges. Harvard law review, vol. 96, 1982.

SALDANHA, Jânia Maria Lopes. Substancialização e efetividade do direito processual civil - a sumariedade material da jurisdição: proposta de estabilização da tutela antecipada em relação ao projeto do novo CPC. Curitiba: Juruá, 2011.

SCHLINK, Bernhard. Liberdade mediante resistência à intervenção estatal: reconstrução da função clássica dos direitos fundamentais. Revista de direito civil contemporâneo, vol. 11. abr-jun. 2017. São Paulo: Revista dos Tribunais, 2017.

SILVA, Manuel Dias da. Processos civis especiais. 2. ed. revista e actualizada pelo professor José Alberto dos Reis. Coimbra: França Amado, 1919.

SILVA, Ovídio A. Baptista da. Curso de processo civil. v.1. 7. ed. Rio de Janeiro: Forense, 2005.

SILVA, Ovídio A. Baptista da. Procedimentos especiais. 2. ed. Rio de Janeiro: Aide, 1993.

SILVA, Ovídio A. Baptista da. Processo e ideologia: o paradigma racionalista. Rio de Janeiro: Forense, 2004.

SILVA. Ovídio A. Baptista da. A "plenitude de defesa" no processo civil. In: Da sentença liminar à nulidade da sentença. Rio de Janeiro: Forense, 2002.

SPIGELMAN, James. The 'new public management' and the courts. Australian law jornal, vol. 75, 2001. Disponível em: <https://papers.ssrn.com/sol3/papers.cfm?abstract_id=1800452>. Acesso em 26.09.2020.

STRECK, Lenio Luiz. Verdade e consenso: constituição, hermenêutica e teorias discursivas. 6. ed. rev. mod. e ampl. São Paulo: Saraiva, 2017.

TARUFFO, Michelle. Razionalità e crisi della legge processuale. Sui confini: scriti sulla giustizia civile. Bologna: Il Mulino, 2002. 
TROCKER, Nicolò. Processo civile e costituzione: problemi di diritto tedesco e italiano. Milano: Giuffrè, 1974.

VORASSI, Kenneth M. England's reform to alleviate the problems of civil process: a comparision of judicial case management in England and the United States. Journal of legislation, v. 30: Iss. 2, Article 8. University of Notre Dame, p. 372. Disponível em:

<http://scholarship.law.nd.edu/jleg/vol30/iss2/8/?utm_source=scholarship.law.nd.edu $\% 2 F j l e g \% 2 F v o l 30 \% 2 F i s s 2 \% 2 F 8 \& u t m \_$medium=PDF\&utm_campaign=PDFCoverP ages>. Acesso em 16/06/2015.

WAMBIER, Luiz Rodrigues; WAMBIER, Teresa Arruda Alvim. Tutela diferenciada. Revista de processo, v.35, n.180, fev. 2010. São Paulo: Revista dos Tribunais, 2010. 